\title{
PREVENTING AND RESOLVING SOCIAL DISSATISFACTION IN SPATIAL MANAGEMENT IN RURAL AREAS
}

\author{
Tomasz Noszczyk, Jozef Hernik, Agnieszka Glowacka, Jaroslaw Taszakowski \\ University of Agriculture in Krakow, Poland \\ t.noszczyk@ur.krakow.pl,.rmhernik@cyf-kr.edu.pl, a.glowacka@ur.krakow.pl, \\ j.taszakowski@ur.krakow.pl
}

\begin{abstract}
The paper addresses the issue of dissatisfaction related to spatial management in rural areas illustrated with an example of southern Poland. In this region, the spatial structure of rural areas is poor, which results, e.g., from substantial fragmentation and scattering of land. Additionally, the Land and Property Register, also known as the real property cadastre for the area is not up to date, and fails to meet social expectations, in particular those regarding the ownership title. Being the basis for calculating the property tax, this register should be reliable and regularly updated, which unfortunately is not always the case. These circumstances may often lead to social dissatisfaction. The aim of the paper is to present surveying and legal processes that may influence prevention and resolution of causes of dissatisfaction and, at the same time, improve the spatial structure of rural areas. The authors have analysed the problems that may result in potential dissatisfaction. The results show that there are activities that may limit or prevent disputes. These include such actions as modernisation of the Land and Property Register or the land consolidation and exchange procedure, including the range of negative impact of motorways.
\end{abstract}

Keywords: dispute, social conflicts, spatial structure, land consolidation, cadastre, Poland.

\section{Introduction}

The notion of "spatial structure" originates from studies on regional structure [1]. According to Friedmann (1955), all social activities are expressed through specific units (elements) that make particular interrelated spatial complexes [2]. Rural spatial structure in Poland is very diversified [3], as is the case in other European countries [4]. The average surface area of a plot is between 0.36 ha in southern Poland to 2.54 ha in northwestern Poland [5]. This variability is correlated with various types of plot arrangements, which was noted by Janus et al. [6]. Similar divergences are found for the number of plots in one holding. In northwestern regions, the number of plots is about 5 ; it varies from 4 to 7 in the central part of the country; and reaches about 10 in southern and southeastern Poland [5]. The situation is particularly difficult in the Małopolska region. The number of plots in a single holding reaches 20 in some municipalities [6], which impacts agricultural land prices [7; 8]. All this makes the rural spatial structure in southern Poland inappropriate. This condition can be improved, for example, through consolidation and exchange of land [9], sale or swapping, or other activities funded by the EU.

Additionally, the Land and Property Register (LPR), also considered equivalent to the property cadastre, which is fundamental for many domains of life, is out-of-date in Poland [10]. This public record kept by starosts, or heads of districts, which is used for such purposes as calculation of real property tax, should be reliable [11; 12] and regularly updated [13], which is not always the case. Plots without access to public roads and excessively scattered or fragmented properties may lead to increased production costs or even unprofitability [6]. Invalid LPR may, in turn, results in incorrect calculation of taxes: buildings are often located on land, which is registered as agricultural land, not built-up area, thus the calculated taxes are inadequate [14].

Rural areas are among the most problematic ones in the whole EU because their social and economic structures are incapable of maintaining prolonged and intensive development [15]. Note that land fragmentation, particularly prevalent in southern Poland, is believed to be one of the most critical problems of the rural spatial structure [16;17]. This is why it is so important to define the notion of land fragmentation properly, so that it reflects the actual situation, which was attempted by Janus et al. [18]. On the other hand, the need to implement spatial structure remedies is urgent as well.

The unfavourable structure of rural areas, invalid data in the LPR, and negative impact of construction of linear structures (such as railway lines, expressways, or motorways) on agricultural and urbanised space may cause social dissatisfaction in rural areas. Most of these instances of dissatisfaction occur in urban areas, which is mainly a result of concentration of various resources (capital, people, and infrastructure) [19]. Social dissatisfaction in rural areas is often of different nature 
and results primarily from the openness of the landscape and large participation of environmental conditions in the development of production, residential, and service functions [19].

The paper attempts to identify and analyse issues and circumstances leading to potential social dissatisfaction in rural areas. The aim of the paper is to present surveying and legal processes that may influence prevention and resolution of dissatisfaction and, at the same time, improve the spatial structure of rural areas.

\section{Study area}

The object of the study is the Małopolskie Voivodeship [first-tier administrative unit in Poland], situated in southern Poland (Fig. 1). The surface of the analysed area is $15,183 \mathrm{~km}^{2}$. It has about 3.37 million inhabitants. It has been selected for the study as it is the most varied region in terms of spatial parameters of plots $[6 ; 20]$; it has recently seen road construction projects, land consolidation procedures [21], and modernisation of the LPR [14]. The unfavourable spatial structure of the Voivodeship may cause social dissatisfaction, which will be demonstrated below.
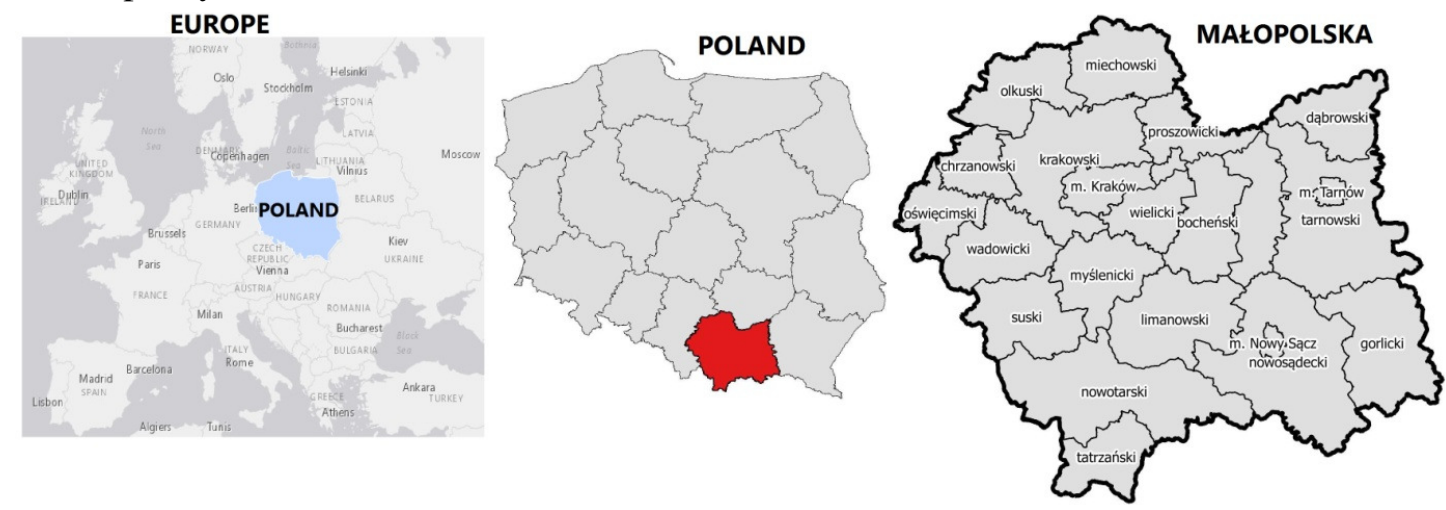

Fig. 1. Location of Małopolskie Voivodeship, Poland - the studied area

\section{Results and discussion}

\section{Causes of dissatisfaction in rural areas}

Factors that cause social dissatisfaction in rural areas include first and foremost invalid LPR, which in turn results in inappropriate calculation of real property tax, flawed structure of rural areas, occurrence of land easement, distorted boundaries on a map in relation to actual use in situ, and negative impact of construction of linear structures (such as railway lines, expressways, or motorways) on agricultural and urbanised space. The factors are shown in Fig. 2.

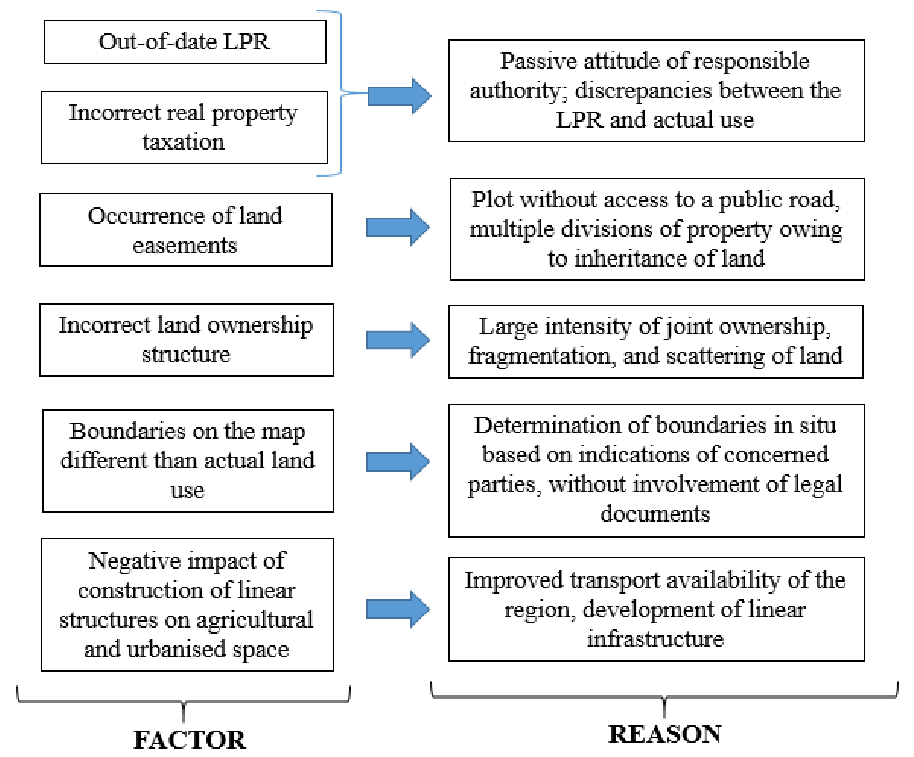

Fig. 2. Factors causing social dissatisfaction 
Surveying and legal tools for preventing and eliminating social dissatisfaction in rural areas are presented below.

\section{Land consolidation and exchange}

The first agricultural management processes that may eliminate social dissatisfaction arising from spatial management in rural areas is land consolidation and exchange, which together with postconsolidation development orders agricultural production space $[9 ; 22]$ by changing plot arrangement and ownership structure. Basic land consolidation processes facilitate changing spatial arrangement and boundaries of individual plots by dividing or merging them into larger areas [23], boundaries of which are adjusted to the existing system of hydraulic structures, roads, and terrain [24]. Table 1 presents the scale of land consolidation works in the Małopolskie Voivodeship.

Table 1

Scale of land consolidation works in the Małopolskie Voivodeship

\begin{tabular}{|c|c|c|c|c|c|}
\hline Municipality & Village & Area, ha & Municipality & Village & Area, ha \\
\hline \multicolumn{6}{|c|}{ Financed by SP-AGR 2006} \\
\hline Jordanów & Łętownia I & 203 & - & - & - \\
\hline \multicolumn{6}{|c|}{ Financed by RDP 2007-2013 } \\
\hline \multirow{3}{*}{ Szczurowa } & Rajsko, Niedzieliska & 590 & Jordanów & Łętownia II & 981 \\
\hline & Barczków & 213 & Sękowa & Męcina Wielka & 938 \\
\hline & Strzelce Małe & 564 & Żabno & Ilkowice & 477 \\
\hline & & & \multicolumn{2}{|c|}{ TOTAL } & 3,763 \\
\hline \multicolumn{6}{|c|}{ Financed by RDP 2014-2020 } \\
\hline \multirow{2}{*}{ Jordanów } & Łętownia III & 1,063 & Charsznica & Chodów & 453 \\
\hline & Wysoka & 1,442 & \multicolumn{2}{|c|}{ TOTAL } & 2,958 \\
\hline Sękowa & Sękowa & $1,157.7920$ & Lubień & Krzeczów & $1,150.8479$ \\
\hline Biecz & Racławice & 634 & Charsznica & Marcinkowice & 428.1186 \\
\hline Żabno & Czyżów-Nieciecza & 644.6122 & $\begin{array}{c}\text { Jerzmanowice- } \\
\text { Przeginia }\end{array}$ & Czubrowice & 829.5307 \\
\hline Szczurowa & Strzelce Wielkie & $1,708.2089$ & \multicolumn{2}{|c|}{ TOTAL } & $5,395.3183$ \\
\hline
\end{tabular}

Land consolidation in the Małopolskie Voivodeship involved 8 precincts or parts of precincts with a total area of 3,966 ha under the Sector Operational Programme 'Restructuring and Modernisation of the Food Sector and Rural Development' (SP-AGR 2006) and Rural Development Programme (RDP) 2007-2013. Three more objects of total surface area of 2,958 ha have been qualified for land consolidation under RDP 2014-2020. An area of almost 7,000 ha spanning six districts of the Małopolskie Voivodeship will be consolidated in 2007-2020 (Tab. 1). Note that over 5,395 ha of land in Małopolska is being prepared for land consolidation under RDP 2014-2020 should funds be relocated and additional means made available.

\section{Infrastructural land consolidation}

The development of the transport network, which enhances the growth of every country, affects rural areas; it often contributes to numerous issues related to the functioning of holdings, and changes general conditions of functioning of the village [25]. Construction of a new road across agricultural land interrupts the natural continuity of the terrain [21], which hinders previous land use [26], and causes local social dissatisfaction. It may be eliminated by applying a specific surveying and legal process, infrastructural land consolidation of plots affected by the road-related changes.

Infrastructural land consolidation works facilitate division of land in such a manner that the proposed road is taken into consideration and the new arrangement of plots is optimal in relation to the road and place of residence of the affected land owners [21]. Construction of agricultural roads during post-consolidation works is an opportunity to design a new road network, which will provide access to individual fields to land owners [27]. Post-consolidation works, which include creation of buffer zones and roadside tree stands, minimise the negative impact of roads on the natural environment. 
Table 2

Scale of motorway-related land consolidation works in the Małopolskie Voivodeship in 2006-2017

\begin{tabular}{|c|c|c|c|c|c|}
\hline Municipality & Village & Area, ha & Municipality & Village & Area, ha \\
\hline \multicolumn{6}{|c|}{ Completed land consolidations } \\
\hline \multirow{7}{*}{ Niepołomice } & Zakrzów & 90 & \multirow{2}{*}{ Brzesko } & Sterkowiec & 167 \\
\hline & Podłęże & 92 & & Wokowice & 259 \\
\hline & Zakrzowiec & 66 & Borzęcin & Bielcza & 329 \\
\hline & Staniątki & 95 & \multirow{6}{*}{ Wierzchosławice } & Łętowice & 61 \\
\hline & Brzezie & 290 & & Bogumiłowice & 35 \\
\hline & Gruszki & 42 & & Gosławice & 200 \\
\hline & Kłaj & 242 & & Rudka & 74 \\
\hline \multirow{4}{*}{ Bochnia } & Stanisławice & 98 & & Komorów & 311 \\
\hline & Cikowice & 62 & & Bobrowniki Małe & 84 \\
\hline & Damienice & 212 & Żabno & Bobrowniki Wielkie & 98 \\
\hline & Proszówki & 193 & \multirow{3}{*}{ Tarnów } & Tarnów obiekt I & 94 \\
\hline \multirow{3}{*}{ Rzezawa } & Krzeczów & 283 & & Tarnów obiekt II & 111 \\
\hline & Rzezawa & 373 & & Tarnów obiekt III & 107 \\
\hline & Borek & 246 & \multicolumn{2}{|r|}{ Total } & 4,314 \\
\hline \multicolumn{6}{|c|}{ Pending land consolidations } \\
\hline \multirow{3}{*}{ Brzesko } & Brzesko & 151 & \multirow{3}{*}{ Lisia Góra } & Zaczarnie & 1,026 \\
\hline & Mokrzyska & 247 & & Stare Żukowice & 628 \\
\hline & Szczepanów & 323 & & Nowe Żukowice & 352 \\
\hline Wierzchosławice & $\begin{array}{l}\text { Wierzchosławic } \\
\text { e }\end{array}$ & 309 & Wojnicz & Biadoliny Radłowskie & 194 \\
\hline Tarnów & $\begin{array}{l}\text { Tarnów } \\
\text { KLIKOWA }\end{array}$ & 437 & \multicolumn{2}{|c|}{ Total } & 3,667 \\
\hline
\end{tabular}

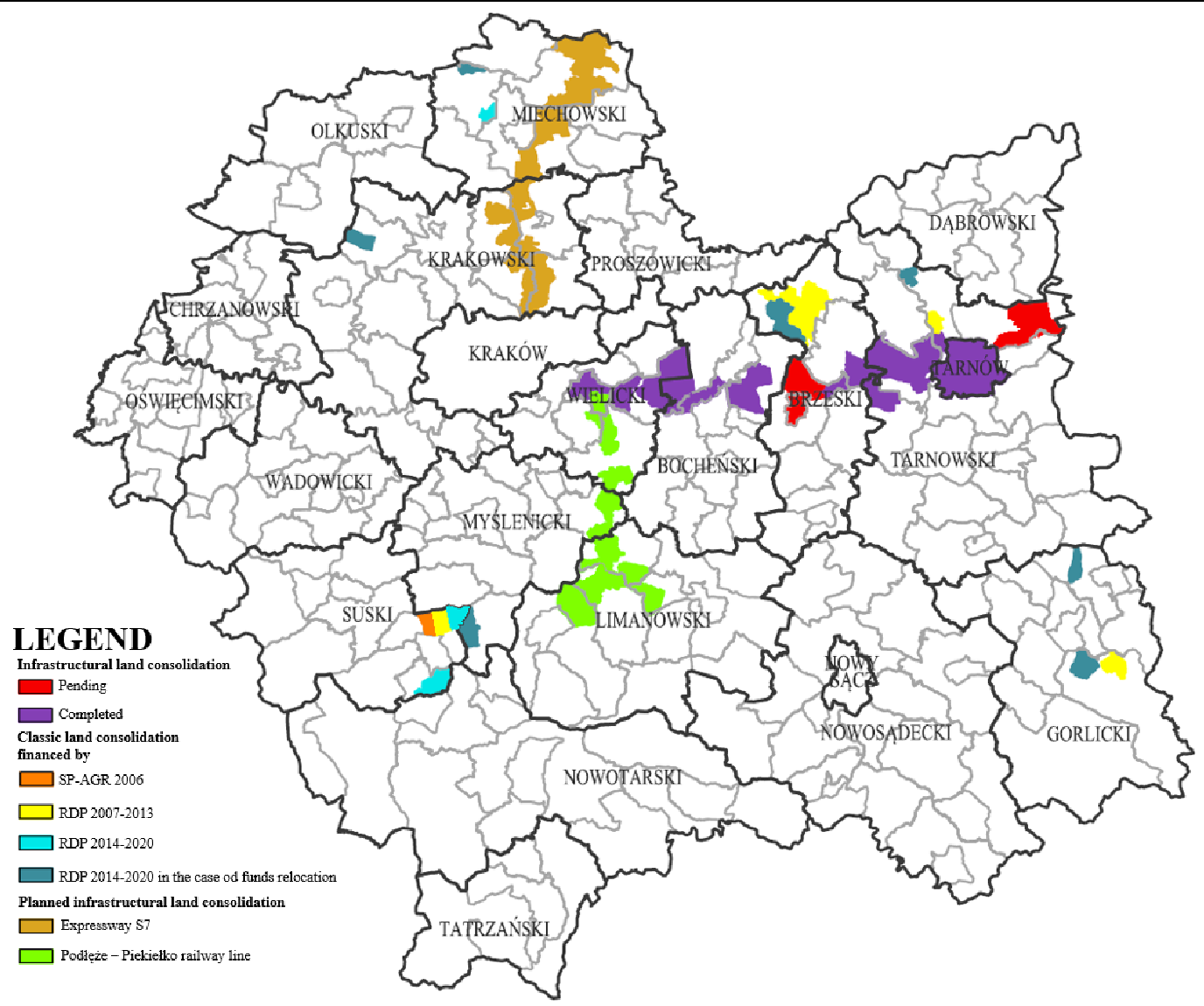

Fig. 3. Spatial location of consolidated objects in Małopolska, Poland 
Land consolidations were commenced in 2006-2017 in 36 precincts in the Małopolskie Voivodeship near Wieliczka, Bochnia, Brzesko, and Tarnów (Tab. 2). The aggregate size of the consolidated areas was 7,981 ha. Their locations are shown in Figure 3. By today, most of the land consolidation works have been completed on an area of 4,314 ha. Nine objects are undergoing land consolidation. It is worth mentioning that there are areas in Małopolska where strong impacts on agricultural space, including aggravation of socio-spatial dissatisfaction, may be expected because of construction of linear structures. Infrastructural land consolidation is planned for such objects as proposed expressway S7 (area of 17,698.98 ha) and Podłęże - Piekiełko railway line (13,277.15 ha).

Land consolidation related to construction of roads has not been popular in Poland; only the Małopolskie Voivodeship and Podkarpackie Voivodeship have substantial experience in this regard owing to the construction of the A4 motorway [25].

\section{Modernisation of the Register}

Invalidity of the LPR in Poland gives rise to extensive dissatisfaction, in particular in rural areas. Discrepancies between recorded data and the in situ state result in incorrect calculation of tax among other things. It often happens that a plot is registered in the LPR as agricultural land, which results in application of agricultural tax instead of real property tax. Consequently, owners of properties with similar surface area and value pay different taxes and the municipality incurs a loss [14]. This may be prevented by applying a specific surveying and legal process, which can eliminate causes of dissatisfaction: modernisation of the LPR.

This issue is acknowledged by many municipalities, but not all have the means to avert it. Modernisation of the LPR is a statutory task of starosts. They are, however, not eager to take it up because it entails no direct benefit for their district.

Michałowice Municipality near Kraków decided to modernise the LPR at its own cost because the mayor found it necessary to levy fair taxes according to the actual land use. The procedure unravelled significant discrepancies between the existing state and register data (Tab. 3). The results of this surveying and legal process have been described in more detail by Noszczyk and Hernik [14].

Table 3

Scale of irregularities in the land and property register (LPR) in the Michałowice Municipality

\begin{tabular}{|l|c|c|c|c|}
\cline { 2 - 5 } \multicolumn{1}{c|}{} & $\begin{array}{c}\text { Area of residential } \\
\text { buildings declared } \\
\text { for taxation }\end{array}$ & $\begin{array}{c}\text { Area of other } \\
\text { buildings (garages, } \\
\text { storage buildings) } \\
\text { declared for taxation }\end{array}$ & $\begin{array}{c}\text { Number of other } \\
\text { buildings declared } \\
\text { for taxation }\end{array}$ & $\begin{array}{c}\text { Area of other } \\
\text { land declared } \\
\text { for taxation }\end{array}$ \\
\hline $\begin{array}{l}\text { Before LPR } \\
\text { modernization }\end{array}$ & $373,847 \mathrm{~m}^{2}$ & $32,238 \mathrm{~m}^{2}$ & $3,000 * *$ & 42.83 ha \\
\hline $\begin{array}{l}\text { After LPR } \\
\text { modernization }\end{array}$ & $421,274 \mathrm{~m}^{2}$ & $112,267 \mathrm{~m}^{2}$ & $7,000 * *$ & 214.84 ha \\
\hline Change $(\%)$ & 13 & 248 & 133 & 402 \\
\hline
\end{tabular}

** Estimates, as it was not possible to determine the exact number of buildings.

Results of the LPR modernisation sparked off some controversies among local residents. Those whose number of buildings subject to taxation or taxable property area increased were not satisfied with the solution. The mayor attempted to alleviate social dissatisfaction arising from this with an administrative decision to remit part of the applied tax. The goal was reached: the residents accepted the new situation and adjusted the condition of their property in order to pay smaller taxes.

Social dissatisfaction related to spatial management in rural areas may be eliminated by land consolidation and exchange, modernisation of the LPR, and infrastructural land consolidation (see Fig. 4). 


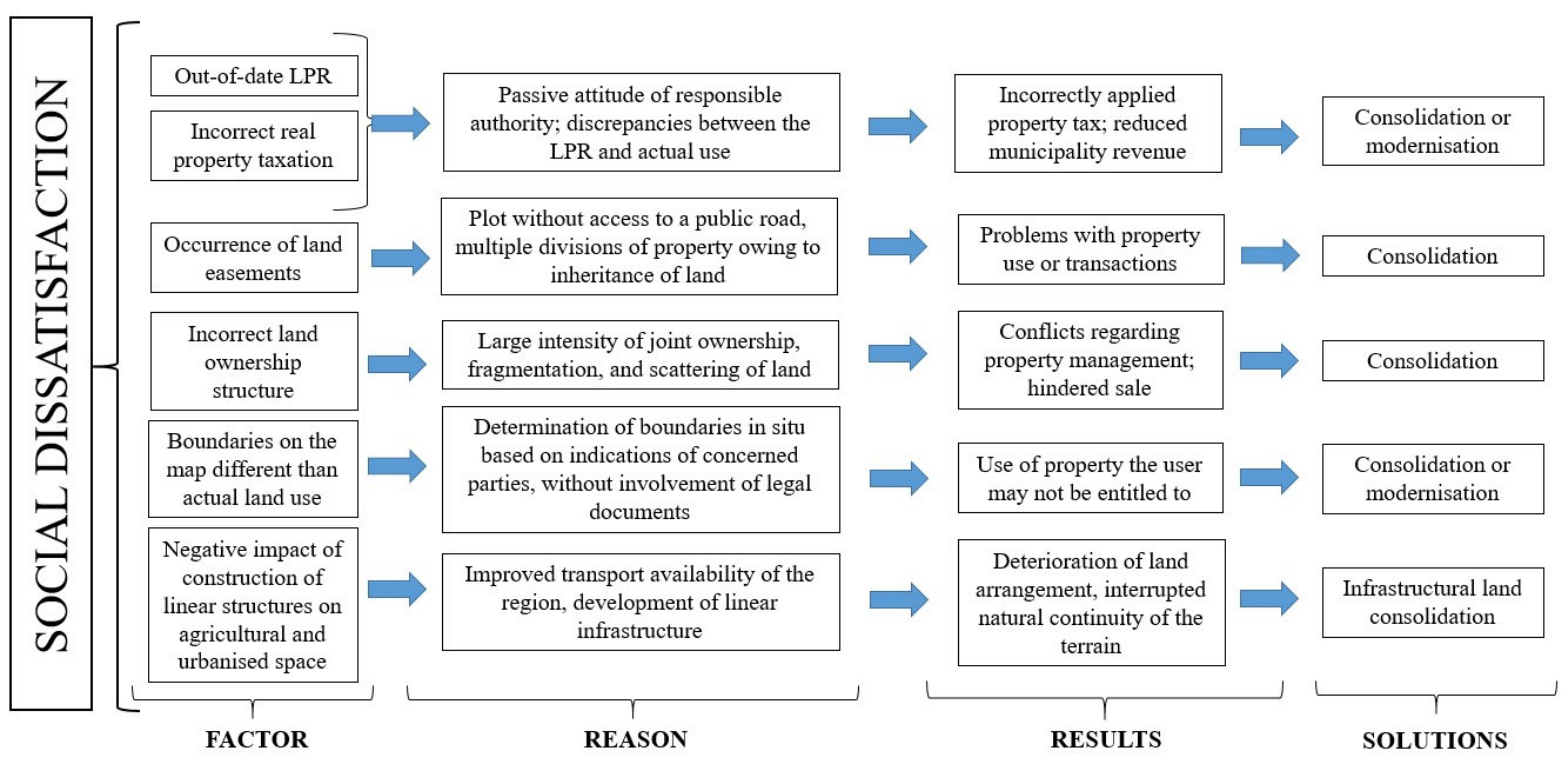

Fig. 4. Classification of social dissatisfaction

\section{Conclusions}

To sum up, social dissatisfaction related to spatial management in rural areas may be eliminated by land consolidation and exchange, modernisation of the LPR, and infrastructural land consolidation On the one hand, they significantly inhibit occurrence of social dissatisfaction; but on the other hand, may give rise to new causes of dissatisfaction, in particular as regards increased taxable land surface area.

Nevertheless, the analysis and balance of the surveying and legal processes gave positive results: there are many more constructive effects for the society and space than drawbacks and limitations. Ultimately, improved spatial structure of land and valid public registers facilitate better management and more efficient sale of property in rural areas.

\section{Acknowledgements}

This Research was financed by the Ministry of Science and Higher Education of the Republic of Poland, project No. DS/3371/KGPiAK/2017.

\section{References}

1. Szymla Z. Determinanty rozwoju regionalnego [Determining factors for regional development]. Wrocław: Zakład Narodowy im. Ossolińskich, 2010. 129 p. (In Polish).

2. Friedmann J. The spatial structure of economic development in the Tennessee valley: A study in regional planning. Chicago: University of Chicago, 1955.

3. Kühne O., Gawroński K., Hernik J. Transformation und landschaft: Die folgen sozialer wandlungsprozesse auf landschaft. Wiesbaden: Springer VS, 2015. (In German).

4. Van Dijk T. Scenarios of Central European land fragmentation. Land Use Policy, vol. 20, 2003, pp. 149-158.

5. Woch F., Borek R. The role of management of the field-forest boundary in Poland's process of agricultural restructuring. Papers on Global Change IGBP, vol. 22(1), 2015, pp. 83-100.

6. Janus J., Glowacka A., Bozek P. Identification of areas with unfavorable agriculture development conditions in terms of shape and size of parcels with example of Southern Poland. 15th International Scientific Conference: Engineering for Rural Development, May 25-27, 2016, Jelgava, Latvia, vol. 15, pp. 1260-1265.

7. Kocur-Bera K. Determinants of agricultural land price in Poland - a case study covering a part of the Euroregion Baltic. Cahiers Agricultures, vol. 25, 2016, article No. 25004. 
8. Czyżewski B., Przekota G., Poczta-Wajda A. The incidence of agricultural policy on the land market in Poland: Two-dimensional and multilevel analysis. Land Use Policy, vol. 63, 2017, pp. 174-185.

9. Muchova Z., Leitmanova M., Petrovic F. Possibilities of optimal land use as a consequence of lessons learned from land consolidation projects (Slovakia). Ecological Engineering, vol. 90, 2016, pp. 294-306.

10. Mika M., Janus J., Taszakowski J., Len P. The use of cadastral databases in planning of land consolidation works. Geographic Information Systems Conference and Exhibition - GIS ODYSSEY 2016, September 05-09, 2016, Perugia, Italy, pp. 165-176.

11. Bandeira P., Sumpsi J.M., Falconi C. Evaluating land administration systems: A comparative method with an application to Peru and Honduras. Land Use Policy, vol. 27, 2010, pp. 351-363.

12. Ilyushina T.V., Noszczyk T., Hernik J. Cadastral system in the russian federation after the modern transformation. Survey Review, 2017, [online] [18.04.2017]. Available at: http://dx.doi.org/10.1080/00396265.2017.1308700.

13. Busko M., Przewiezlikowska A. The problem of demonstrating cadastral changes in surveying documentation. Geographic Information Systems Conference and Exhibition - GIS ODYSSEY 2016, September 05-09, 2016, Perugia, Italy, pp. 50-62.

14. Noszczyk T., Hernik J. Modernization of the land and property register. Acta Scientiarum Polonorum-Formatio Circumiectus, vol. 15(1), 2016, pp. 3-17.

15. Dudzinska M., Kocur-Bera K. Community education and integrated organization of rural areas based on land consolidation processes in Poland. 8th International Scientific Conference on Rural Environment, Education and Personality, May 15-16, 2015, Jelgava, Latvia, vol. 8, pp. 34-41.

16. Boztoprak T., Demir O., Coruhlu Y.E. Comparison of expropriation and land consolidation on the regulation of agricultural land. Sigma Journal of Engineering and Natural Sciences-Sigma Muhendislik Ve Fen Bilimleri Dergisi, vol. 34(1), 2016, pp. 43-55.

17. King R., Burton S. Land fragmentation - notes on a fundamental rural spatial problem. Progress in Human Geography, vol. 6, 1982, pp. 475-494.

18. Janus J., Mika M., Leń P., Siejka M., Taszakowski J. A new approach to calculate the land fragmentation indicators taking into account the adjacent plots. Survey Review, vol. 49, 2017, [online] [1.03.2017]. Available at: http://www.tandfonline.com/doi/full/10.1080/00396265.2016.1210362.

19. Henderson S.R. Managing land-use conflict around urban centres: Australian poultry farmer attitudes towards relocation. Applied Geography, vol. 25, 2005, pp. 97-119.

20. Salata T., Prus B., Janus J. Planning as trigger for land use changes. 14th International Scientific Conference: Engineering for Rural Development, May 20-22, 2015, Jelgava, Latvia, vol. 14, pp. 729-734.

21. Sobolewska-Mikulska K. The possibilities of using infrastructural land consolidations in the process of restructuring the spatial structure of rural areas. Infrastructure and Ecology of Rural Areas, vol. 1/II/2012, 2012, pp. 41-51.

22. Sklenicka P. Applying evaluation criteria for the land consolidation effect to three contrasting study areas in the Czech Republic. Land Use Policy, vol. 23, 2006, pp. 502-510.

23. Pasakarnis G., Maliene V. Towards sustainable rural development in Central and Eastern Europe: Applying land consolidation. Land Use Policy, vol. 27, 2010, pp. 545-549.

24. Muchova Z., Leitmanova M., Petrovic F., Bazik J., Konc L., Sinka K. Land Consolidations in Slovakia, Step Forward, Two Steps Back? Ekologia (Bratislava), vol. 34, 2015, pp. 380-391.

25. Janus J., Taszakowski J., Korta G. Identification issues of the areas intended to be covered with land consolidation procedures in the case of implementation of the linear investment based on Malopolska Province. Infrastructure and Ecology of Rural Areas, vol. I/2/2017, 2017, pp. 333-346.

26. Villarroya A., Puig J. Urban and industrial land-use changes alongside motorways within the Pyrenean Area of Navarre, Spain. Environmental Engineering and Management Journal, vol. 11, 2012, pp. 1213-1220.

27. Bacior S. Investigations of variability of the motorway on agricultural land as an example A1 motorway section. Acta Scientiarum Polonorum-Formatio Circumiectus, vol. 15(4), 2016, pp. 29-39. 